\title{
Water Allocation as a Planning Tool to Minimise Water Use Conflicts in the Upper Ewaso Ng'iro North Basin, Kenya
}

\author{
Jeniffer Kinoti Mutiga • Shadrack T. Mavengano • \\ Su Zhongbo • Tsehaie Woldai • Robert Becht
}

Received: 23 September 2009 / Accepted: 29 March 2010 /

Published online: 28 May 2010

(C) Springer Science+Business Media B.V. 2010

\begin{abstract}
Inadequate water resources management and a general decline in rainfall have aggravated water scarcity problems in the Upper Ewaso Ng'iro North Basin in Kenya. Furthermore, water use conflicts in the basin have escalated in recent decades due to increased competition for available water resources. Excessive abstraction of the declining river water mainly for irrigation in the Mount Kenya and Nyandarua foot zones often leads to reduced water flow during the dry seasons, greatly affecting downstream water users. Increased water use in the basin coupled with deterioration of the vegetative cover has resulted in reduced water flows in the Ewaso $\mathrm{Ng}$ 'iro river and its major tributaries. In addition, lack of sufficient knowledge about available water resources and current lack of coordination in water resources management in the basin often result in water deficits which have hampered development in the downstream catchment. The goal of this study was to match the water requirements of various competing sectors in the basin with the available water resources in order to attain both economic and ecological sustainability. To achieve this, GIS techniques were used to quantify the spatial and temporal stream flow. The Water Evaluation and Planning (WEAP) model was applied to evaluate water resources development based on an equilibrium scenario of the current water demand. Water use was simulated for five different sectors (domestic, livestock, wildlife, irrigation and reserve). The analyses revealed that high water demand for irrigation was the main cause of excessive water abstraction particularly in the upstream catchments, giving rise to water shortages and consequently, water use conflicts downstream. The study, therefore, recommends that rainwater harvesting be promoted in the basin in order to improve water availability for productive use.
\end{abstract}

J. K. Mutiga ( $\otimes) \cdot$ S. T. Mavengano $\cdot$ S. Zhongbo $\cdot$ T. Woldai $\cdot$ R. Becht Faculty of Geo-Information Science and Earth Observation (ITC), University of Twente, PO Box 6, 7500 AA, Enschede, The Netherlands e-mail: mutiga@itc.nl 
Keywords Water abstraction - Water evaluation and planning model

Water demand • Water allocation • Water use conflicts • Scenario development • Ewaso Ng'iro North

\section{Introduction}

Many countries in the world are facing formidable fresh water management challenges due to increased competition for the increasingly scarce natural resource. Overexploitation of water resources continues to be the greatest constraint on sustainable agricultural development, an important factor to poverty alleviation. Water has been recognized as an essential component of food security (UNWATER 2006), with the World Summit on Sustainable Development in 2002 drawing more attention to the importance of water resources management in meeting the Millennium Development Goals (MDGs; UN 2002).

Water resources sustainability means using the natural resource wisely and protecting the complex ecosystems with future generations in mind. But sustainability will not be achieved with current patterns of resource consumption and use (UN 2005). It is therefore of paramount importance to rational planning and decision making in equitable water management. This must be undertaken within the widely accepted integrated approach at all levels of the society.

Mountains often function as water towers of the earth and are rich in biological diversity, making them target areas for recreation. Approximately $12 \%$ of the world population depends directly on mountain resources (UNCED 1992). Mountain environments are essential for survival of global ecosystems, but their function as water towers is rapidly under threat as competition for natural resources increases. They are susceptible to accelerated erosion, landslides and rapid loss of habitat and genetic diversity (Odermatt 2004). There is therefore a need to focus more on these regions to preserve their status as major water sources.

The high plateau of the Upper Ewaso Ng'ro North Basin in Kenya and the mountain foot zones referred to as the "White Highlands" during the colonial period consisted of ranches and large farms. After independence in 1964, the basin experienced changes in land use as land was subdivided into smaller plots for agropastoralists as people resettled from overpopulated foot zone areas. As a result, growth points such as towns and densely populated small scale farms as well as with large scale technical horticulture farms have been formed in the mountain foot zones while game parks and tourist resort centres occupy the dry lowlands of the basin. The population increased from 50,000 in 1960 to 500,000 in 2000 and has put demand for water resources under pressure (Kiteme and Gikonyo 2002). As more land is being converted to irrigated land to grow crops mainly for international markets, farmers now place their water intakes high up on the mountain in the tributaries of Ewaso Ng'iro river. At the same time, pastoralists and small scale farmers are establishing small scale irrigation schemes (Wiesmann et al. 2000). These developments affect communities, wildlife and the ecology downstream of the basin as water becomes scarcer. For instance, 98 abstraction points within a $30 \mathrm{~km}$ river reach, provide water to about 30,000 people. About $97 \%$ of this abstracted water is being used to irrigate only $9 \%$ of the total basin area (Aeschbacher et al. 2005), and thus greatly contributing to water shortages downstream and hence conflicts. 
The Upper Ewaso Ngiro North Basin has a high economic status in the country due to its intensified agriculture, forestry and game reserves attracting tourists from all over the world. It offers a great deal of beautiful scenery. Therefore, careful management and negotiation of water resources is a priority in order to mitigate growing water crises and conflicts at local and national levels. While a lot of research has been done in the basin on water resources aspects, focus has been around the Mt. Kenya area which is the main contributor of the Ewaso $\mathrm{Ng}$ 'iro river (Aeschbacher et al. 2005; Ngigi et al. 2006; Notter et al. 2007) while no studies have been undertaken in the downstream catchments. Yet, in recent years (especially 1999 to 2002) the lower catchments have experienced water crises to an extent previously unknown (Aeschbacher et al. 2005).

Population growth and the intensification of irrigation on agricultural lands in the foot zones and along the rivers in the plateau have dramatically increased water demand over the past decade (Notter et al. 2007). As a result, water abstraction for irrigation, livestock and domestic use have severely stressed the water resources, particularly during dry seasons causing conflicts between upstream and downstream water users. There is therefore a need to understand the spatial and temporal water availability and to formulate a tool for planning and decision making in prioritisation of water allocation in the basin. However, given the complexity of the system and the interactions between water supply and demand, a large-scale water supply management tool would be useful for decision makers when formulating water management strategies for coping with future changes in water demands (Chung et al. 2008).

To contribute towards this goal, the current study adopted and applied Water Evaluation and Planning (WEAP) model as a decision support system (DSS) to assess water availability and investigate the impacts of different water allocation scenarios (water demand management strategies) aimed at meeting various sectorial water demands in the Upper Ewaso Ng'iro North basin in Kenya.

\section{The Study Area}

Kenya is divided into five major drainage basins namely, Lake Victoria, the Rift Valley, the Athi River, the Tana River and the Ewaso Ng'iro Basin. However, only two of these basins, (Lake Victoria and the Tana River) are said to have surplus water resources while the others often experience major water deficits (FAO 2003). This study was conducted in the Upper Ewaso Ng'iro North Basin in Kenya.

\subsection{Location of the Upper Ewaso Ng'iro North Basin}

The Ewaso Ng'iro Basin is the largest of the five major drainage basins in Kenya covering an area of $210,226 \mathrm{~km}^{2}$. The Upper Ewaso Ng'iro North Basin lies in the upstream of the Ewaso Ng'iro North Basin between $0^{\circ} 15^{\prime}$ south and $1^{\circ} 00^{\prime}$ north, and $36^{\circ} 30^{\prime}$ east and $37^{\circ} 45^{\prime}$ east with an area of approximately $15,300 \mathrm{~km}^{2}$. The main Ewaso Ng'iro river originates in the Nyandarua mountains although most of its flow $(50 \%)$ comes from the tributaries which drain the Mt. Kenya slopes (Jaetzold and Schidt 1983). Mt Kenya receives high rainfall giving rise to perennial rivers which, in the dry season, form the main source of freshwater in the semi-arid Laikipia plateau 
northwest of the mountain, and the arid lowlands of the lower Ewaso Ngiro Basin. However, groundwater resources remain largely untapped and thus Mt. Kenya is regarded as the water tower for the basin.

The basin drains from the Rift Valley escarpments to the west, the Nyandarua ranges to the south-west, Mount Kenya to the south, the Nyambene hills to the east, and the Mathews range to the north while the downstream outlet is at Archer's Post (Fig. 2). 5CA8, 5D05 and 5E03 are flow monitoring stations in the Ewaso-Narok, Ewaso-Mt. Kenya and lowlands catchments respectively (Fig. 1).

The topography is dominated by Mt. Kenya and the Nyandarua ranges in the south and the Nyambene hills to the east of the basin (Fig. 2). Altitude ranges between $862 \mathrm{~m}$ above mean sea level (a.s.l) at Archer's Post to 5,200 m at the Mt. Kenya summit (Jaetzold and Schidt 1983). The mountain slopes consist of deeply incised $\mathrm{V}$-shaped valleys where elevation varies from 2,500 $\mathrm{m}$ to $4,000 \mathrm{~m}$ a.s.l. The

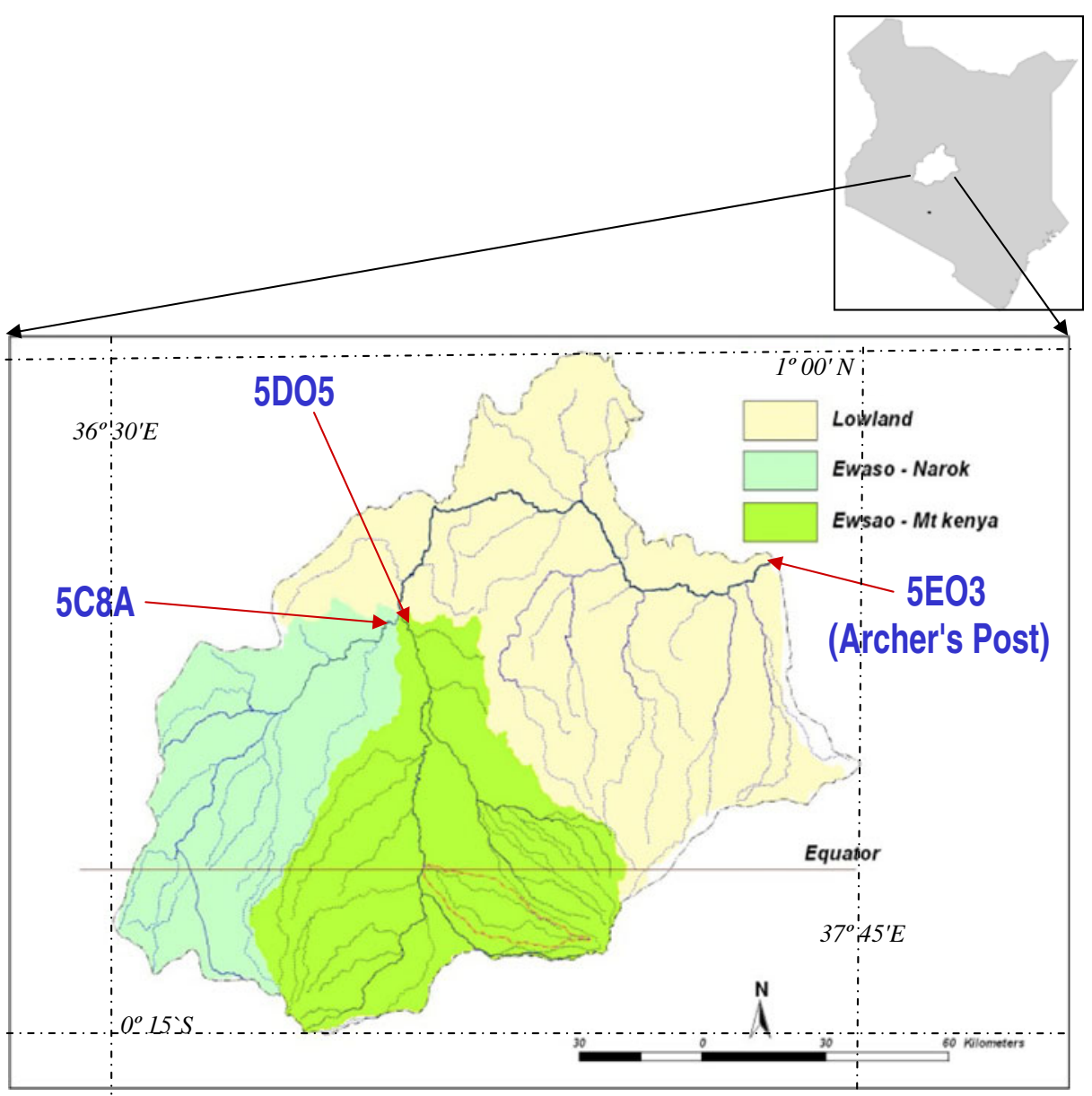

Fig. 1 Map showing the location of the upper Ewaso Ngiro North basin, Kenya 
gentle undulating Laikipia plateau at an elevation of 1,700 $\mathrm{m}$ to 1,800 $\mathrm{m}$ a.s.l occupies most of the central region of the basin (Fig. 2).

The large elevation differences in the basin give rise to various climatic zones, ranging from humid to arid. Annual rainfall pattern shows spatial and temporal variations from $300 \mathrm{~mm}$ in the north eastern areas of the basin to $1,500 \mathrm{~mm} / \mathrm{year}$ in the Nyandarua ranges with a mean annual rainfall of about $700 \mathrm{~mm} / \mathrm{year}$ in the basin (Berger 1989; Decurtins 1992; Liniger et al. 2005). There are three main rainfall seasons comprised of monsoon controlled long rains (March to May), followed by continental rains that are caused by humid airstreams from the west (July to August), and short rains (October to November) dominated by air masses due to the movement of the Inter-Tropical Convergence Zone (ITCZ). The continental rains are of great importance as they provide an extended growing period for crops and pasture development. The most distinct dry periods occur from December to February and in the month of September. The mean annual temperatures in the basin range from below $10^{\circ} \mathrm{C}$ at the top of Mt. Kenya to over $24^{\circ} \mathrm{C}$ at Archer's Post, the outlet of the basin (Berger 1989).

Previous studies show that $70 \%$ to $90 \%$ of the downstream flow in the semi-arid environments of the basin comes from the mountains (Gichuki et al. 1998; Liniger et al. 2005; Notter et al. 2007) and more than $60 \%$ of the basin inhabitants irrigate their crops using water from the Ewaso Ng'iro river and its tributaries (Wiesmann et al. 2000). Other sources of water in the basin include groundwater (boreholes and shallow wells) and flood water usually stored in small dug water pans.

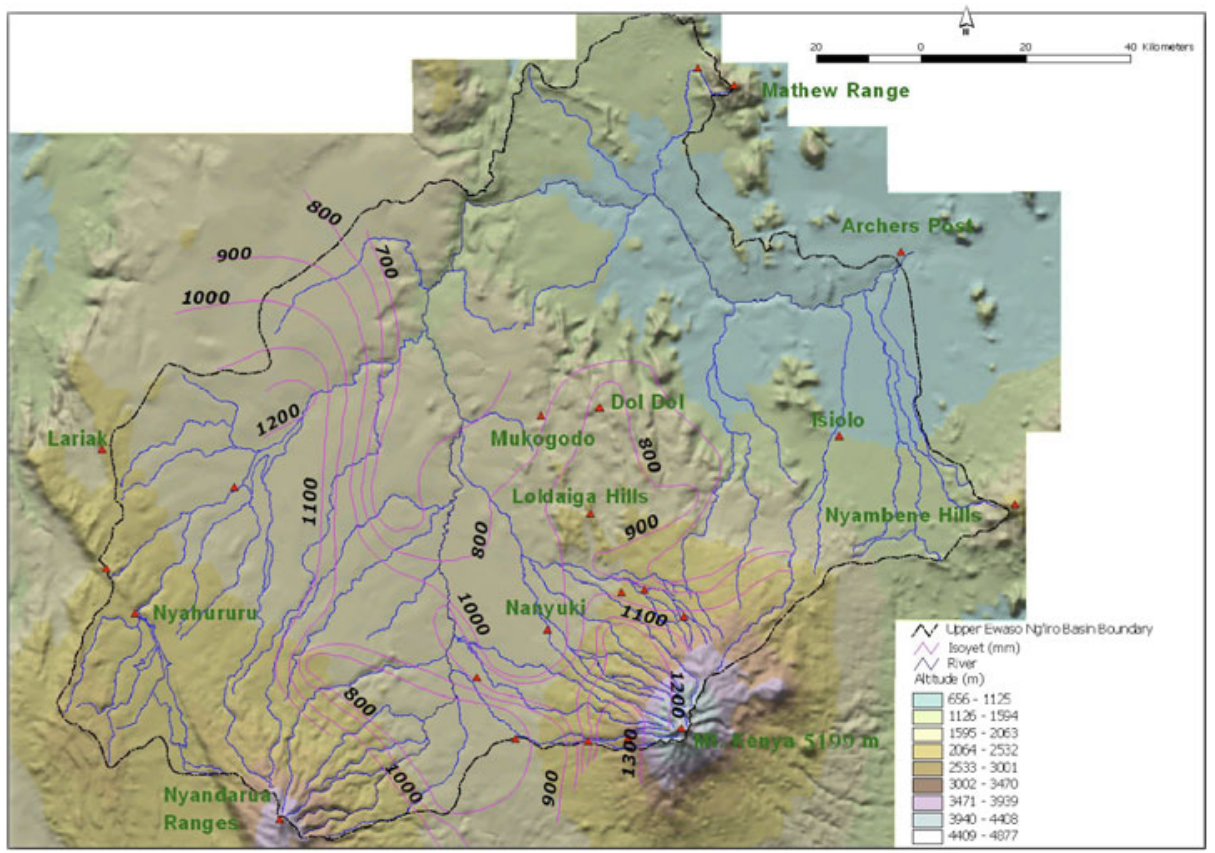

Fig. 2 Topographic variation in the upper Ewaso Ng'iro North basin, Kenya 
Due to the arid nature of most parts of the basin, the atmospheric demand for water is very high with daily potential evaporation varying from 3 to $8 \mathrm{~mm} /$ day (Mutiga et al. 2010). Gichuki et al. (1998) observed that only 3\% of the basin (mountain moorlands) receives a water surplus while 50\% experiences water deficits of more than $1,000 \mathrm{~mm} /$ year. This is because potential evapotranspiration in the basin increases with decreasing altitude while precipitation decreases with decreasing altitude (Wiesmann et al. 2000; Mutiga et al. 2010) implying that water deficits increase with decreasing altitude away from the mountain. Moreover, if the amount of water abstracted for various uses is considered, the situation becomes worse thus water use conflicts become more critical downstream of the basin. Conflicts on the distribution of the available water resources are common here, mostly because of the spatial variation of the availability resulting from climatic conditions in addition to increased demand.

Large scale horticulture farms and an increasing number of small scale farms upstream of the basin all using water for irrigation contributes to further increase in water shortages particularly for the downstream users. Pastoralists, who occupy the lower parts of the basin, also use the river water for their domestic use and for watering their animals. About $60 \%$ to $95 \%$ of the available river water in the upper reaches of the basin is abstracted during the dry season with up to $90 \%$ of the total abstraction being illegal, resulting in decreased river flows in the lowlands (Kiteme and Gikonyo 2002; Notter et al. 2007). This has negatively affected downstream

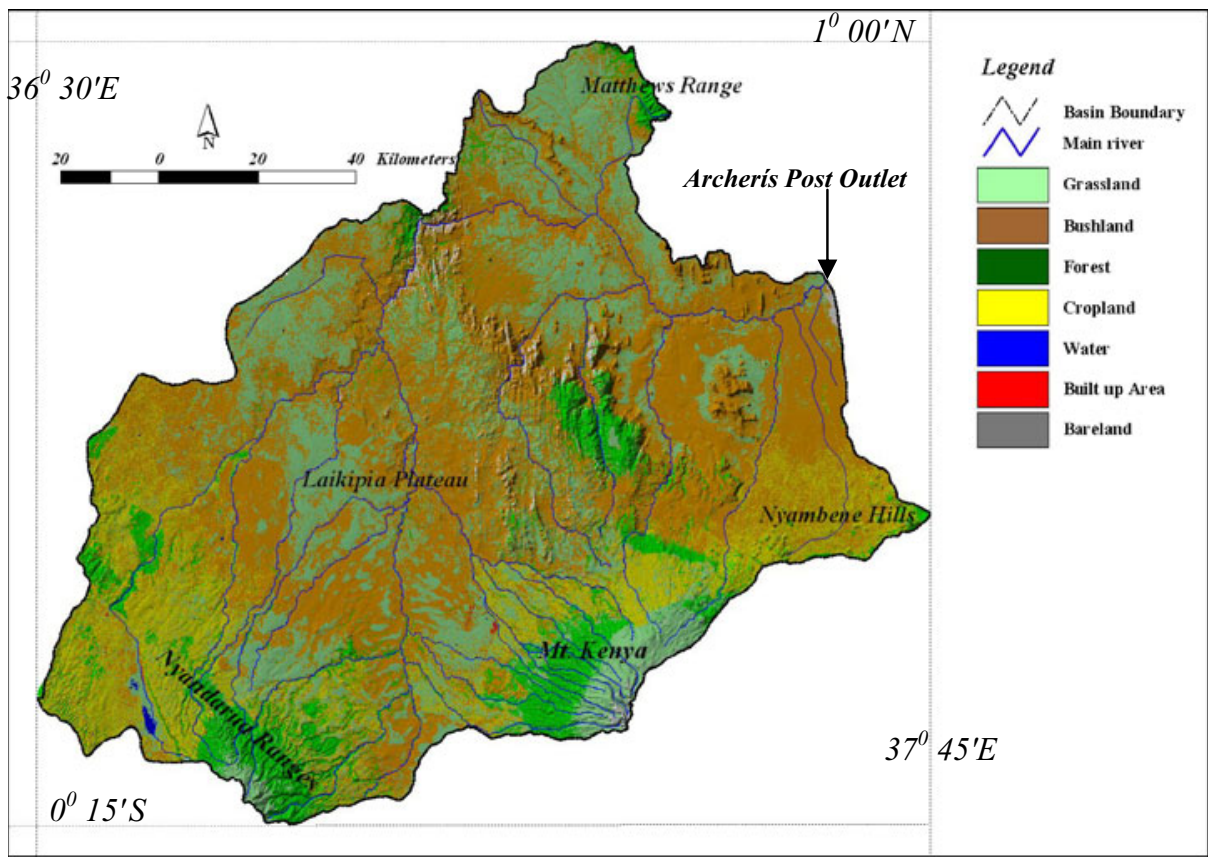

Fig. 3 Land cover types in the upper Ewaso Ng'iro North basin, Kenya obtained from Landsat ETM+ of 2002 
populations as well as wildlife and the associated tourism activities leading to water use conflicts among different water resource users.

Population growth is estimated at $5 \%$ to $6 \%$ per annum (Kiteme and Gikonyo 2002), mostly as a result of immigration from the communal areas in search of jobs in the horticulture farms or from the neighbouring agricultural potential districts through land sub-divisions. In the upper Ewaso Ng'iro, the population averages 212 people per $\mathrm{km}^{2}$ in the highlands, 60 people per square kilometer in the midland and $24 / \mathrm{km}^{2}$ in the lowlands due to differences in land use (Ngigi 2006).

The main forms of land use in the basin are forestry, mixed farming, ranching and nomadic pastoralism. Mt. Kenya, Nyandarua ranges and the Nyambene hills are covered with forests; while the plateau areas are covered with bushes and grasses used mainly for communal grazing. Cultivated lands (small to large scale commercial farms) are mostly found at the foot of the mountains (Fig. 3).

\section{Materials and Methods}

\subsection{WEAP for Water Allocation}

WEAP, which is an object-oriented computer modeling package is an Integrated Water Resources Management (IWRM) tool designed for simulation of water resources systems and trade-off analysis. The tool operates on the premise that water supply is defined by the amount of precipitation that falls on a watershed or a series of watersheds, with the supply progressively becoming depleted through natural watershed processes, human demands and interventions, or enhanced through watershed accretions. These processes are governed by a water balance model concept that defines watershed scale evaporative demands, rainfall-runoff processes, groundwater recharge, and irrigation demands (Yates et al. 2005a, b; Purkey et al. 2007).

The model simulates water system operations within a river system with basic principles of water accounting on a user-defined time step, usually a month. Simulation allows the prediction and evaluation of "what if" scenarios and water policies such as water conservation programs, demand projections, hydrologic changes, new infrastructure and changes in allocations or operations (Raskin et al. 1992; Yates et al. 2005a, b; Purkey et al. 2007; SEI 2008). Thus WEAP is considered as an integrated water management tool for evaluating water use and allocation with a greater focus on balancing supply and demand in a swift and transparent way. Since no comprehensive work has been previously done on IWRM in the study area, adopting a user-friendly interface such WEAP could enhance building a shared understanding of the water supply and demand system, problems and their causes; exploring and expanding solution options; and developing and evaluating alternatives for the Upper Ewaso Ng'iro North basin (Ubbels and Verhallen 2001).

WEAP model was applied by simulating recent base year or 'business as usual' account, for which water availability and demand was determined. This information was obtained from different water users/stakeholders in the basin through either group discussions or individual interviews conducted during fieldwork campaigns. The model was first configured for the whole Upper Ewaso Ng'iro North basin in form of a continuous set of three sub-catchments (Fig. 1). It was then used to simulate 
alternative scenarios to assess the impacts of different development and management options. This was possible since the model has the ability to optimize water use in the catchment using an iterative linear programming algorithm with the objective of maximizing the water delivered to demand sites according to a set of user-defined rules (SEI 2008).

The application was defined by time frame, spatial boundaries, system components and configuration of the problem. The Current Account, which is the calibration step of the model, provided the actual water demand, resources and supplies for the system. Scenarios built on the current account enabled the exploration of the impact of alternative policies on future water availability and use. Construction of different scenarios was based on alternative sets of policies, which were evaluated with regard to water sufficiency, costs and benefits (SEI 2008). During this study, WEAP analyses were underpinned on the available data for the three sub-basins (Fig. 1) on a monthly time step. Fieldwork carried out in the basin also provided some crucial data not found in the existing archives such as water abstraction points and crops types under irrigation.

\subsection{Surface Water Supply}

The long-term variation in surface water at Archer's Post station of the Ewaso $\mathrm{Ng}$ 'iro river shows clearly the reduction in the flow discharge. The minimum annual discharge at Archer's Post (5EO3) decreased proportionally to the increase of water abstraction in the upper catchments of the basin. For example, in low rainfall periods, February is one of the worst months of the year with the river reach upstream of Archer's Post drying up, clearly showing the limitations for further development potential of surface water.

\subsection{Water Demands}

\subsubsection{Domestic Water Supply}

The domestic water supply requirement within the basin is primarily concentrated in the urban and rural centers which have been identified and lumped for the three sub-catchments (Fig. 1). The centers are mainly concentrated in the sub-humid districts of Nyandarua, Nyeri, and Meru located on the slopes of Nyandarua ranges and Mt. Kenya. However, in the arid and semi arid districts (Isiolo and Samburu), urban and rural centers are generally concentrated close to major water sources such as permanent rivers, ephemeral streams, springs, wells and boreholes. About $70 \%$ of the total population in the basin is dispersed in rural communities. The total consumptive water requirement was based on 1999 population census, with a total human population of about 500,000 in the basin. A unit water requirement of 501 per person per day (Gleick 1996) was used for WEAP domestic water demand calculations.

\subsubsection{Livestock and Wildlife Water Demand}

A unit water requirement of 50 1/day for each livestock unit was given as the unit consumption rate to estimate the water demand for all livestock and wildlife in the 
basin. Livestock and wildlife figures were also based on 1999 census data, estimated to about 700,000 for the basin.

\subsubsection{Reserve Requirement}

The key principles of the Kenya Water Act (2002) are sustainability and equity. The Act asserts that, in conjunction with using water resources to promote social and economic development, it is essential to protect the environment while ensuring that the water needs of present and future generations can be met. This is partly achieved by leaving enough water in a river, referred to as the "reserve", to maintain its ecological functioning and as such, it was assigned the highest priority over all other water uses and must strictly be met before water resources can be allocated to any other uses.

\subsubsection{Irrigation Water Demand}

Irrigation is the largest water user in the basin. The total area under irrigation in the basin is about $46 \mathrm{~km}^{2}$ (commercial, small-scale and community schemes) with most of the farms being located on the north-western slopes of Mount Kenya. Most crops in the area are only irrigated in the dry season, (February to March and July to September). Since there is no data available on the exact amount of water used for irrigation and farmers do not know how much water they use for irrigation, irrigation water demand for the basin was calculated using the reference evapotranspiration (ETo) and effective precipitation (P) concept as outlined in FAO-56 (Allen et al. 1998). Total water demand for irrigation was thus estimated by multiplying the total area under irrigation with the average water requirement for the main crops (Liu et al. 2009) in the basin using the following irrigation parameters (Reference potential Evaporation, ETo, average crop factor, $\mathrm{Kc}=0.80$ (Table 1) and irrigation efficiency, $\dot{\eta}_{1}=40 \% \dot{\eta}_{2}=85 \%$ for the reference (business as usual) and improved irrigation efficiency account respectively in the basin.

\subsection{Modeling Demand and Supply}

Decisions on water allocation require methods which allow for changes in water availability to be estimated spatially and temporally under a range of climatic conditions. Hydrological models provide the means to investigate the relationships

Table 1 Average crop coefficients for the common crops grown in the basin

Adopted from FAO-33;

Source: Allen et al. (1998)

\begin{tabular}{lll}
\hline Crop & $\begin{array}{l}\text { Average Kc for the } \\
\text { total growing period }\end{array}$ & Average Kc \\
\hline Beans & 0.88 & \\
Cabbage & 0.75 & \\
Maize & 0.88 & \\
Onions & 0.85 & \\
Peas & 0.88 & \\
Pepper & 0.75 & \\
Potatoes & 0.82 & \\
Tomatoes & 0.82 & \\
Wheat & 0.85 & \\
Rose flowers & 0.70 & \\
\hline
\end{tabular}


between climate, human activity and water resources (Van Heerden et al. 2008). Supply-oriented simulation models are not always adequate for allocation of water resources, environmental and policy issues, therefore an integrated approach for water resources development has emerged, which places water supply projects in the context of demand-side issues, as well as issues of water quality and ecosystem preservation (Yates et al. 2005a, b). WEAP model was selected for this study as it incorporates all these values into a practical tool for water resources planning (SEI 2008). Water demand baseline data for the basin were obtained from the Water Resources management Authority (WRMA) regional office database for the year 2000 which was considered as the base year for this study.

Irrigation is the highest water consumer taking about $80 \%$ of the total water available in the basin. The total water demand in the basin is estimated to be about $950,000 \mathrm{~m}^{3} /$ day. An important aspect of WEAP is its ability to distinguish between the "business as usual" scenario and the alternative policy scenarios. The "business as usual" also referred to in this study, as the reference scenario, incorporates current trends in both economic and demographic development, water supply available, water use efficiency and water pricing policies. Thus, the "business as usual" scenario analysis provides a reference against which the effects of alternative policy scenarios were be evaluated. A schematic diagram of the WEAP model for the Upper Ewaso Ng'iro North Basin in Kenya (Fig. 4) shows all the demand sites and various water sources (streams, groundwater, and dams).

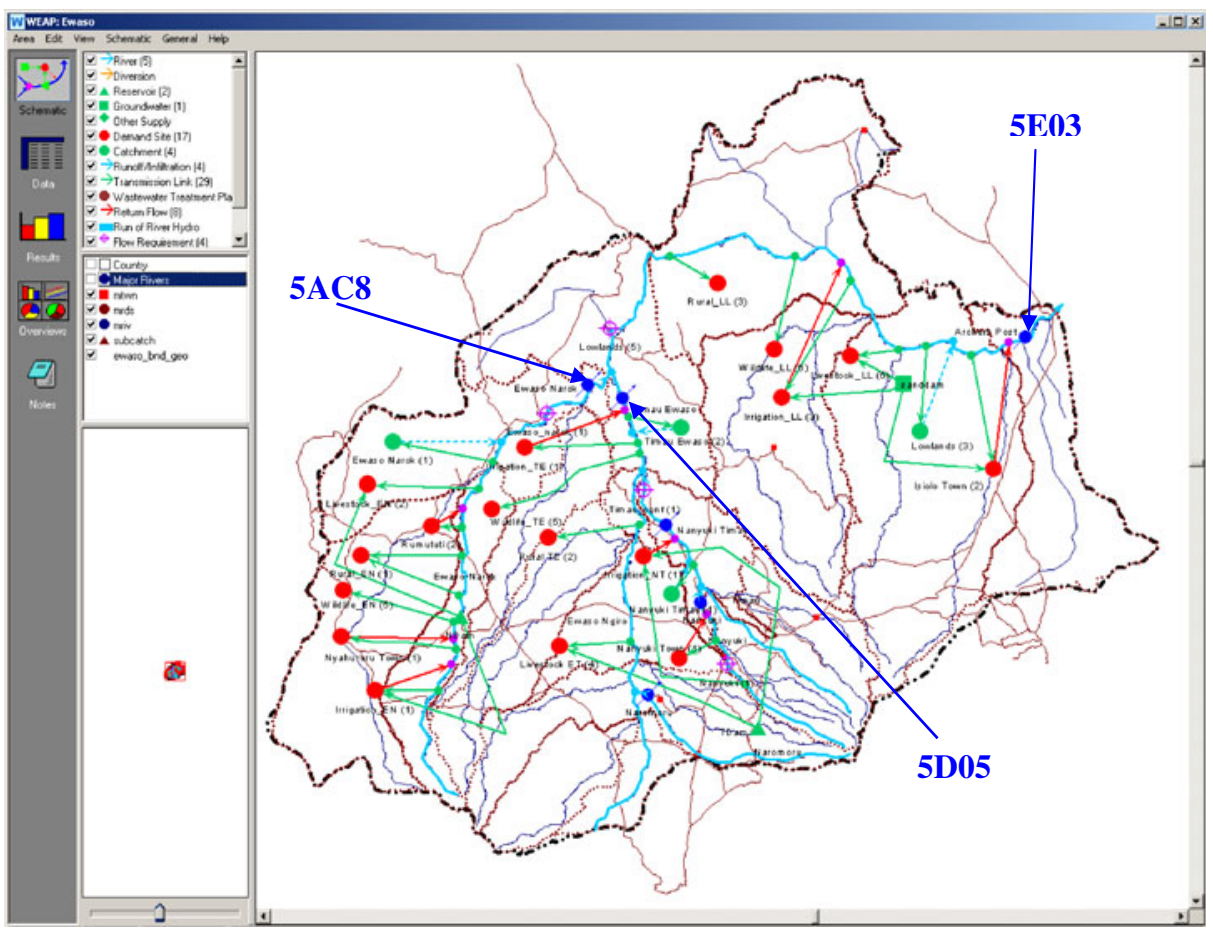

Fig. 4 Schematic diagram showing the configuration of the WEAP model for upper Ewaso Ng'iro North Basin in Kenya 
Fig. 5 Simulated WEAP and observed flow at gauge 5DO5

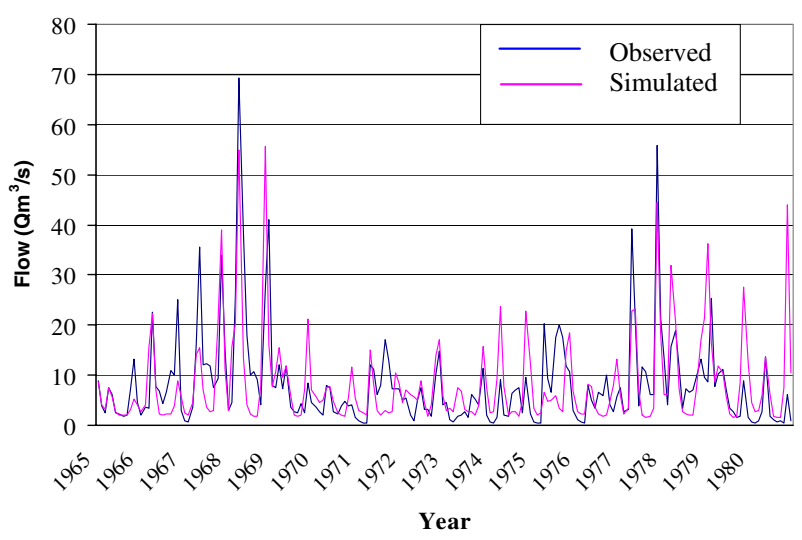

The model was calibrated and validated using the 1965-1980 data sets from three flow monitoring stations in the basin (Fig. 1). This period was selected as it represents the naturalized flow of the basin since irrigation activities started in the early 1990s (Aeschbacher et al. 2005). Since there is no automatic calibration routine in the model, visual comparison of the observed and the simulated time series monthly flow was carried out for gauge 5DO5 which had adequate clean data for the selected period (Fig. 5). Calibration was necessary in order to evaluate performance of the model. The percentage error in the simulated mean annual river flow using WEAP compared to the observed (measured) was found to be $0.18 \%$ with good simulations obtained during the dry seasons (Figs. 5 and 6).

In general, the model simulation of the stream flow compared favourably well with the observed/ measured flow, exhibiting similar seasonal variability while capturing the general inter-annual trends. The model parameters were used to derive the discharge for all streams in the basin for the entire planning period (2000-2015) and subsequently allocate the available water to various existing demand sites in the basin (Fig. 5).

The available data for the observed stream flow for the gauge station 5DO5 were used for simulation of discharge from the rainfall-runoff model within WEAP.

Fig. 6 Cumulative WEAP simulated and observed stream flow at gauge 5DO5

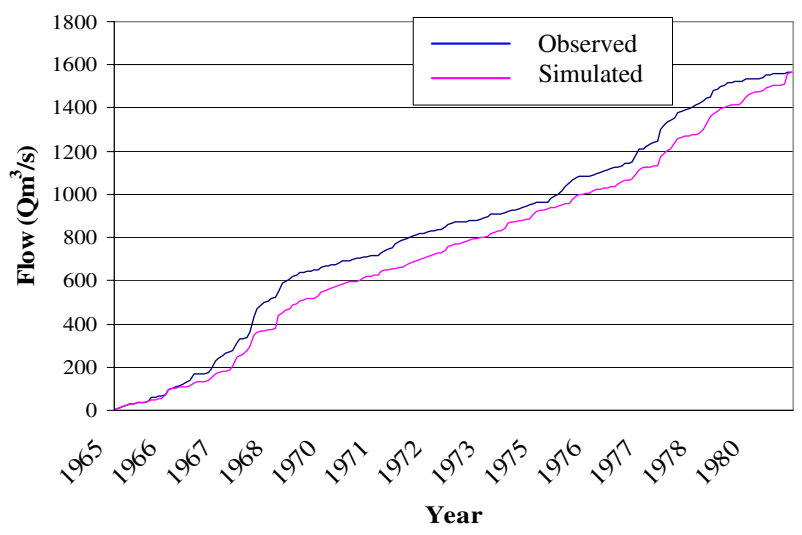


Rainfall-runoff method was chosen since it best suited the characteristics of the basin, and required only one input variable (precipitation). Model simulation facilitated the assessment of water availability in the basin both in space and time.

\section{Results and Discussions}

Estimated current water demands for the five different sectors were used for the reference scenario (Fig. 6) from the "naturalized" stream flow (1965-1980). This period was selected because irrigation activities started in the early 1990s (Aeschbacher et al. 2005), which is believed to be the beginning of water use conflicts in the basin, as observed by Kiteme and Gikonyo (2002). Demands were fixed for the entire planning period representing an "equilibrium" type of scenario with a total annual water demand of $113 \mathrm{MCM}$ for all sectors in the basin. Groundwater supply from 96 working boreholes was included to meet part of the demand. An average supply rate of $2 \mathrm{~m}^{3} / \mathrm{h}$ per borehole was used to meet part of the livestock and population demands, particularly in the basin lowlands. However, the total water demand almost double (220MCM) by 2015 as a result of increase in both human and animal population in addition to changes in land use (increased area under irrigation) as illustrated in Table 2 below.

The reference scenario is helpful in understanding the current trend or the real situation in relation to water resources management in the basin. This scenario was used in designing future contingency plans for basin aimed at improving its environmental integrity.

\subsection{Water Allocation: Reference Scenario}

Water allocation models must accurately represent the significant features of water resource systems within any catchment. Ideally they should simulate water availability and demand (Etchells and Malano 2005). Priorities for different demand sites in the basin were set on the basis of the true order of priorities that exist within any catchment (i.e. between different sectors) as well as the probable realities of upstream-downstream allocations. Demand priority in this case, represented the level of priority for allocation of the available water resource (SEI 2008; Al-Omari et al. 2009). This means, for example, that all the demand sites with the highest priority would be supplied first before moving to lower priority sites until all the demands are met or all the available resources are used, whichever comes first.

It was observed that water rights in some farms already do exist. For example, in the "business as usual" scenario, the Mt. Kenya and the Ewaso-Narok

Table 2 Water demand distribution for different sectors in the reference scenario

\begin{tabular}{lcccc}
\hline Sector & $\begin{array}{l}\text { 2000 demand } \\
(\mathrm{MCM})\end{array}$ & Percent & $\begin{array}{l}\text { 2015 demand } \\
(\mathrm{MCM})\end{array}$ & Percent \\
\hline Domestic & 11 & 10 & 23 & 10 \\
Livestock & 7 & 6 & 13 & 7 \\
Wildlife & 4 & 3 & 9 & 4 \\
Reserve & 1 & 1 & 3 & 1 \\
Irrigation & 90 & 80 & 172 & 78 \\
Total & 113 & 100 & 220 & 100 \\
\hline
\end{tabular}


Table 3 Priorities for different demands in the "business as usual scenario"

\begin{tabular}{llllll}
\hline Sub-Basin & Domestic & Livestock & Wildlife & Reserve & Irrigation \\
\hline Mt. Kenya & 1 & 2 & 4 & 9 & 3 \\
Narok & 1 & 2 & 4 & 10 & 3 \\
Lowlands & 5 & 6 & 8 & 11 & 7 \\
\hline
\end{tabular}

sub-catchments, (Fig. 1), supply priority was given as (1) since they are both located in the upstream of the basin but on different supply sources while the laikipia lowlands demand sites, a priority (2) was given as it is dependent on these two upstream catchments. This means that demand from all upstream activities would have to be met first, before the demands located in the lower reaches of the basin are met and this represent the "business as usual or the current account" scenario (Table 3). However, in order to promote equitable water allocation in sectors, prioritization of water use rights (Table 4) is a prerequisite in mitigating water use conflicts in the basin. It should be noted that the current account provides a snapshot of actual water demand, resources and supplies to the system for the current or baseline year.

Irrigation, which constitutes all irrigated farms in the mountain foot zones, had the largest annual water demand of $90 \mathrm{MCM}$, about $80 \%$ of the total water demand, while wildlife in the laikipia lowlands had the least demand of about 1\% (Fig. 7). Stream flow during a dry season (February 2005) showed virtually no flow after the confluence of Ewaso-Narok and Mt. Kenya catchments. It was observed during fieldwork surveys that flow only occurred up to Ewaso-Narok swamp, located a few kilometres upstream of the gauge 5AC8 (Fig. 1).

Other activities found downstream of the basin such as tourism, which depend on wildlife, are the most affected during this period and have to resort to alternative means of water supply. This scenario was used to replicate the present situation (present state of affairs) as much as possible and the results revealed that in February, when water use conflicts are highest, stream flow from the upper catchments did not get to the middle reaches of the basin (Ewaso-Narok and Mt. Kenya rivers confluence) meaning that the stream flow at 5EO3 (Archer's Post) originated mainly from the laikipia lowlands.

The total unmet demand for water (Fig. 8) is of importance for planning purposes as it can easily be linked to the economy of an area. As a matter of fact, it forms the main reason for conflicts as other sectors are deprived of the economic benefit from the water resources. Unmet demand in this case is defined as the quantity of water that cannot be physically delivered from the river during a part of the year.

Through field assessment, it was observed that the Ewaso $\mathrm{Ng}$ 'iro river often dried up for a considerable stretch from Archer's Post, when no rainfall was received in January, February, June and/or September, depending on the rainfall season. During these months, groundwater formed the main water supply for sectors in the lower catchments, and though boreholes yield $2 \mathrm{~m}^{3} / \mathrm{h}$, this was still insufficient for other

Table 4 Priorities for different demands in accordance with The Water Act (2002)

\begin{tabular}{llllll}
\hline Sub-basin & \multicolumn{1}{l}{ Domestic } & Livestock & Wildlife & Reserve & Irrigation \\
\hline Mt. Kenya & 1 & 2 & 1 & 1 & 3 \\
Ewaso-Narok & 1 & 2 & 1 & 1 & 3 \\
Lowlands & 1 & 2 & 1 & 1 & 3 \\
\hline
\end{tabular}


Fig. 7 Water demand in different sectors for the reference scenario in the upper Ewaso Ngi'ro North Basin, Kenya

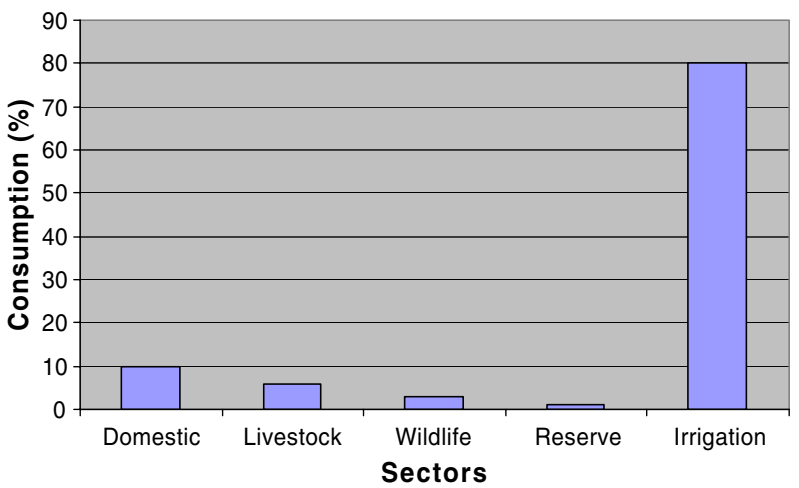

demands such as agriculture and wildlife. However, other alternatives such as deep wells not modeled in this study due to insufficient data available might be seen as alternative sources of supply. Nevertheless, the situation is likely to deteriorate in future due to ever increasing demand for water. Therefore, immediate action is required to address the declining stream flow, the main cause of the current water use conflicts in the basin particularly between upstream and downstream users.

\subsection{Scenario Analysis}

Scenarios are defined as alternatives or a set of assumptions (operating policies, pricing, and demand management strategies and alternative supply sources). Changes in these assumptions could either grow or decline at a varying rate over the planning horizon. Scenario projections for this study were established in WEAP based on economic, demographic, hydrological, and technological trends starting from a "reference" or "business-as-usual" point. For example, it was observed that increasing human, livestock and wildlife populations (doubling), caused a significant increase in water demand and hence an increase in unmet water demand if no appropriate measures are put in place to counter the effect.

Similarly, changes in land use such as increasing the area under irrigation (doubling) resulted in an increase in water demand and consequently increasing the

Fig. 8 Unmet demand in different sectors for the Reference scenario in the basin

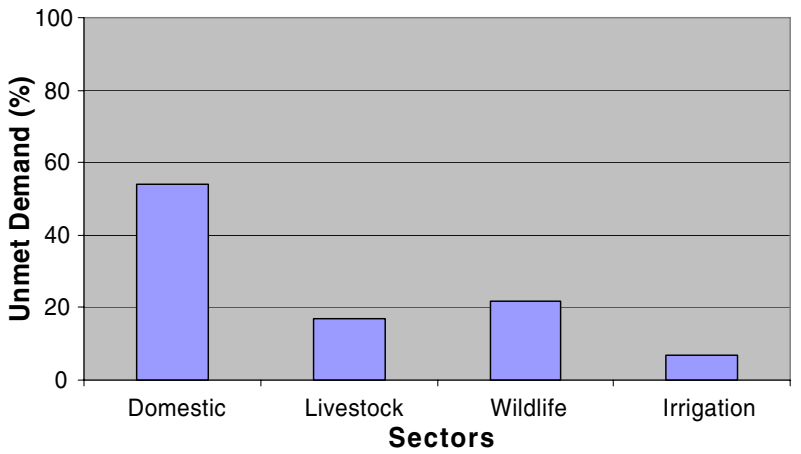


Fig. 9 Water demand (a) and unmet water demand (b) in different sectors with different assumptions in the basin

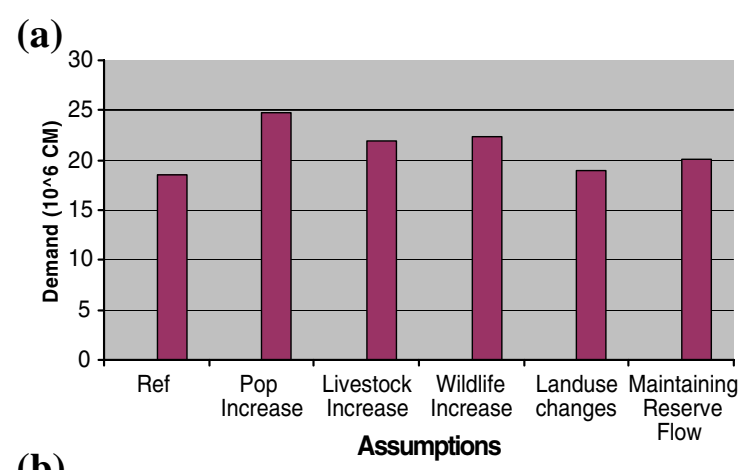

(b)

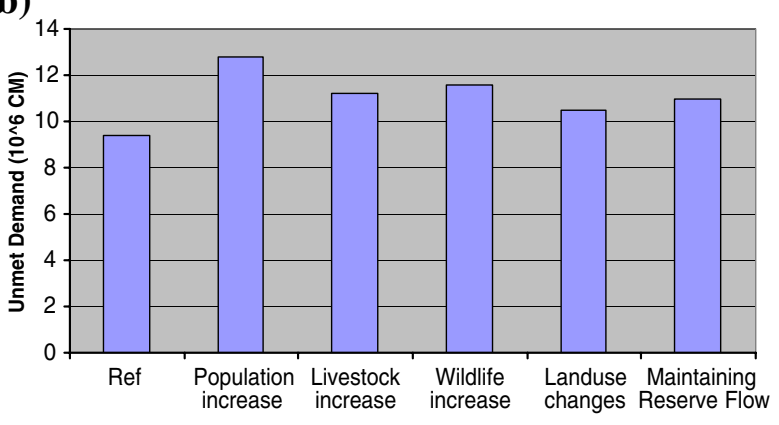

Assumptions

unmet demand (Fig. 9a and b). During the planning horizon (2000-2015), three different scenarios were constructed reflecting alternative paths for future water resources development in the basin. These scenarios included alternatives such as the construction of storage dams for flood harvesting, increasing water use efficiency, maintaining reserve flow, allocating water equitably and exploiting ground water (Fig. 10). During scenario analysis, WEAP model was found to be sensitive to various input parameters (population growth, land use changes, groundwater storage, and irrigation efficiency) as shown on Fig. 9a.

Fig. 10 Unmet water demands for alternative scenarios

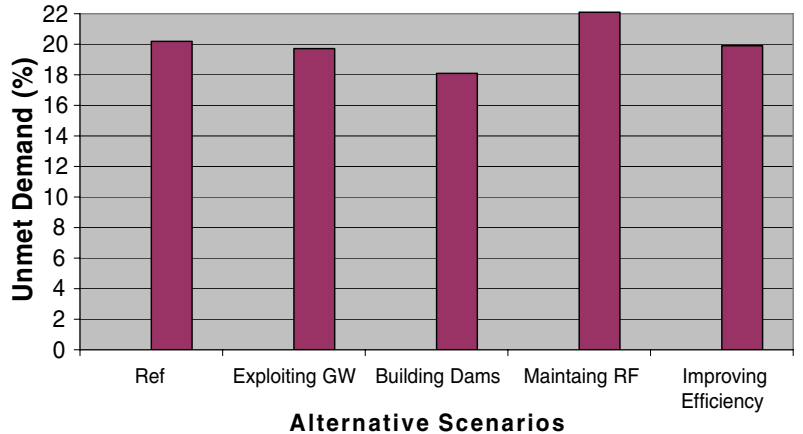

Alternative Scenarios 


\subsubsection{Irrigation}

Agriculture contributes about $30 \%$ to the total regional gross domestic product (RGDP) while the other sectors (tourism, transport, communication, business services and community social services) contribute the remainder. Using irrigation water productivity rates of US $\$ 1.24 / \mathrm{m}^{3}$ for crops (Sayeed 2001) and US $\$ 0.06 / \mathrm{m}^{3}$ for livestock and assuming that water productivity rate for both tourism and social services is US $\$ 2.4 / \mathrm{m}^{3}$, the economic value, various services derive from the use of water was estimated. All these services are dependent on the "reserve", which is defined as the quantity and quality of water required to satisfy basic human needs for all people who are or may be supplied from the water resources and to protect aquatic ecosystems in order to secure ecologically sustainable development and use of the water resource as defined in The Water Act (2002).

\subsubsection{Water Rights Allocation Scenario}

The Water Act (2002) provides an enabling environment for the implementation of water conservation and demand management measures. During this research, such measures were considered to be an important approach when reconciling water demands and water supplies in the Upper Ewaso Ng'iro North basin. When there is insufficient water, the allocation plan needs to promote equitable distribution to mitigate resource based conflicts by formulating strategies such as prioritization of water use. This process is guided by the priority as described in The Water Act (2002) which ranks the reserve and domestic water requirements above other uses (Table 4). In all the scenarios, therefore, domestic water use is given priority (1) as it is mandatory according to this legislation. Boreholes in the laikipia lowlands are set at supply priority (1) for domestic and livestock use, to augment water supplies during dry periods. This scenario satisfies water demand downstream according to the water allocation hierarchy in The Water Act (2002).

For example, in February 2005, stream flow improved at Archer's Post according to this scenario, but irrigated fields upstream experienced shortages and this affected the RGDP of the area.

\subsubsection{Demand Management Strategies}

WEAP model is unique in its capability to represent the effects of demand management strategies on water systems. Irrigation is the only activity that allows an evaluation of the effects of improved technologies. These strategies consist of measures, which farmers can take (e.g., switch crops, change planting dates, use water saving technologies or grow high value crops) to minimize water demand. This is important, particularly in the rapidly intensifying horticultural industry in the basin, where flowers such as roses fetch the highest profits as they are destined for the overseas markets.

\subsubsection{Improving Irrigation Efficiency Scenario}

Improving water use efficiency entails shifting from less efficient systems (flood or furrow, portable sprinklers) to more efficient ones (center pivot and drip irrigation) usually regarded as the gold standards of irrigation efficiency (Perry et al. 2009). The main water use in the basin is irrigation ( $80 \%$ in the "reference" scenario). In 
this study, efficiency relates to water use at farm level and includes the efficiency of conveyance, distribution and application. Gravity pipeline systems are common in the upper catchments while furrow systems dominate in the lower areas where slopes allow for open channel water conveyance for flood irrigation methods. Gravity pipeline systems account for about $29 \%$ of the total abstraction points which translates to about $97 \%$ of the total abstracted volume, with the hydraulic structures said to be "geared towards meeting the full water demand for the upstream abstractors" before excess water is released downstream (Rural-Focus-Ltd 2004). In this scenario, irrigation efficiency is assumed to have improved from the current $40 \%$ to $85 \%$.

Improved irrigation efficiency can be achieved by managing demand through lining of the intake canals, proper maintenance of gravity pipelines and promoting water saving technologies for irrigation such as drip irrigation instead of the commonly used portable overhead sprinklers. It was observed during fieldwork, that some crops grown in the open would produce better yields if grown under greenhouse conditions in addition to good irrigation scheduling if high efficiencies are to be obtained. Implementation of this strategy significantly reduced daily irrigation water demand for the basin by about $18 \%$, thus making more water available for the other sectors.

\subsubsection{Groundwater Use}

Groundwater potential and safe abstraction rate in the Mt. Kenya sub-basin is estimated to about 142.4 MCM (JICA 1992) and can be used to complement surface water. It was established that if the existing boreholes (about 96 in good working condition) could be further developed, their average safe yield rate could improve to 10 and $6 \mathrm{~m}^{3} / \mathrm{h}$ in the Mt. Kenya and Ewaso-Narok sub-basins, respectively. This means that in order to take advantage of the existing groundwater potential, more boreholes need be drilled in the upstream part of the basin where recharge rates are high. The rate of replenishment of groundwater in this area is estimated to be about 120-220 MCM/year (JICA 1992). The upper sub-basins can therefore produce sufficient water supply from groundwater abstraction to meet the total water demand by using only about $5 \%$ of the recharge. However, groundwater levels in these areas vary from 18 to over $200 \mathrm{~m}$ in depth resulting in high drilling, equipping and pumping costs.

\subsubsection{Building Storage Dam Scenario}

Development of reservoirs is part of the plan by the Ewaso Ng'iro North Development Authority (ENNDA) and other stakeholders in the basin for supporting socioeconomic development activities. Analysis of results from this scenario showed that the water prioritization policy, would cause more water flow downstream leaving part of irrigation water demands unmet. For the "business as usual" scenario, water availability would increase when the demand was lowest and source development would only be possible if water could be stored into dams.

The results from this study indicate clearly, that an integrated approach for the development of water resources in the basin is necessary in order to meet the water requirements of all sectors to avoid competition and conflicts in water use and at the same time optimize the use of limited water resources. Dams can be multi-purpose and used for storage, domestic supply, flood regulation or irrigation. Suitable dam sites have been identified in the upstream of the basin, based on both bio-physical 
and socio-economic factors. Two dams were incorporated in this scenario and result analysis showed that building the dams would reduce the unmet water demand by about $5 \%$ (Fig. 10). This is considered to be a significant contribution towards making more water available to the downstream users as well as reducing the current water use conflicts in the basin.

It was observed that unmet water demand would decrease if groundwater was be used to complement the available surface water. Similarly, the building of flood water storage dams would significantly reduce currently unmet water demand. However, if reserve flow would be secured, the unmet demand would drastically increase thus escalating an already miserable situation. If implemented, this scenario would deny some economic sectors, particularly irrigated agriculture, substantial economic benefits (US \$10 million to US \$62 million).

Improving irrigation efficiency would improve supply, but in February, August, September, downstream water demand for wildlife would not be met (therefore affecting tourism) during low rainfall seasons unless the cropping calendar is changed. Improvement of farm technologies to achieve high crop yield and quality would improve the downstream flow while ensuring that water demands in Laikipia lowlands are met.

\section{Conclusions}

Currently, forecasts on how water development or growth will change over time are only possible if reforms in the agricultural sector which constitutes $65 \%$ of the total water demand are implemented. During the fieldwork campaigns, it was observed that people are relocating from the mountain areas to the lowland areas, resulting in more land sub-divisions into small plots unviable for any agricultural activity. This has affected the growth of tourism and livestock in the basin which depends on the performance of the agricultural sector under the prevailing limited water resources. The scenario based on the current situation in the basin can provide insights in understanding the cause of water use conflicts and hence facilitate in formulating appropriate recommendations. By linking model outputs with water productivity data, it is possible to make preliminary estimates of the economic costs for each scenario. Based on simple assumptions, the estimates are believed to be indicative of the economic costs and benefits for different water management strategies.

Water allocation phase begins when available water resource is near depletion due to increased demand and managing it becomes very critical. Efforts to increase the productivity or value of every drop of water become so crucial. As competition for water increases, water is re-allocated from "lower value" uses (irrigation) to "higher value" uses (domestic and tourism). The Water Act (2002) sets priorities for water allocation with irrigation demand, being the lowest in the hierarchy. If this policy is enforced, it is believed that flow would improve downstream (even during the driest month of February) to an average of about $2.44 \mathrm{~m}^{3} / \mathrm{s}$. This scenario would ensure that in the event of low flows, downstream releases are given the highest priority.

Results from this study, have revealed that improving irrigation efficiency would significantly improve water supply requirements downstream and consequently reduce the unmet water demands. This can be achieved through improved control and timing of water application during irrigation, ensuring easy implementation of sup- 
plementary irrigation strategically to overcome seasonal dry spells. It is important to introduce suitable crops that can withstand the dry spells and encourage communities to practice crop rotation with a sense of economy in mind.

Nevertheless, a greater potential for better water resource management, to improve water use efficiency lies in soil and water conservation practices for rainfed agriculture. Under rain-fed agriculture, water conservation aims at reducing runoff and evaporation losses while increasing water supply to the soil and thus to the plants. This would also increase the base flow from ground water especially in the downstream areas of the basin. Given the highly seasonal flow variability of the Ewaso Ng'iro river, which depends on rainfall occurrence, it would be necessary to install flood storage dams in strategic but suitable locations aimed at stabilizing its stream flow. Thus building dams upstream of the basin would help meet water demands in laikipia lowlands. Large commercial farms should also be encouraged to install reservoirs with at least 3 months storage capacity for the dry season in order to reduce demand from surface river water supplies. Release of stored runoff from these reservoirs during the dry season would support the downstream communities, thus achieving flow stabilization at Archer's Post through the middle reaches.

It is recommended that sand dams be constructed downstream since they are ideal for the lowland areas where evaporation losses are too high for a viable surface dam. Besides, sand dams could be used to increase the base flow and subsequently recharge the groundwater aquifers within the basin. For the basin to maximize its earnings, it is highly recommended that rainwater harvesting be promoted to improve water availability and reduce the current water use conflicts between upstream and downstream users.

Capacity building and promoting change in the attitude of users towards rainwater harvesting and water saving techniques are also crucial. Agriculture not only creates jobs but also contributes significantly to the GRDP of the area. Farm development incentives by the government could assist farmers in putting water infrastructure especially for irrigation in place. Furthermore, the formation of water user associations (WUAs) is of importance as it integrates ideas from different stakeholders who can freely discuss problems, set goals and define their solutions. These platforms will ensure a high level of stakeholder involvement and participation in designing and implementing development goals for the entire basin.

\footnotetext{
Acknowledgements The work reported here is part of ongoing research on "Planning of System Innovations in Watersheds: Spatial Mapping of Environmental and Hydrological Determinants in the Ewaso Ngiro North River Basin, Kenya", funded by the Dutch government under the Netherlands Fellowship Programme (NFP) and The International Institute for Geo-Information Science and Earth Observation (ITC).

The authors wish to thank ITC, for the immense support both financially and morally accorded during the implementation of this study. Many appreciations are also being extended to the Director of the Centre for Training and Integrated Research for ASAL Development (CETRAD), based in Nanyuki, Kenya for providing the necessary spatial data and research platform for this study. We are greatly indebted to the International Foundation of Science (IFS) for their generous financial support, Water Resources Management Authority (WRMA), Nanyuki and the Ewaso Ng'iro North Development Authority (ENNDA) in Isiolo, Rural Focus limited in Nanyuki, and all the farmers in the Upper Ewaso Ng'iro North Basin for their support and cooperation they demonstrated during the fieldwork campaigns for this study.
} 


\section{References}

Aeschbacher J, Liniger H, Weingartner R (2005) River water shortage in a highland-lowland system. Mt Res Dev 25(2):155-162

Allen RG, Pereira LS, Raes D, Smith M (1998) Crop evapotranspiration-guidelines for computing crop water requirements-FAO irrigation and drainage paper 56. FAO, Rome

Al-Omari A, Al-Quraan S, Al-Salihi A, Abdullah F (2009) A water management support system for Amann Zarqa Basin in Jordan. Water Resour Manag 23:3165-3189

Berger P (1989) Rainfall and agro-climatology of the Laikipia Plateau, Kenya. African Studies Series A7. Institute of Geography, University of Bern, Switzerland

Chung G, Lansey K, Blowers P, Brooks P, Ela W, Stewart S, Wilson P (2008) A general water supply planning model: evaluation of decentralized treatment. Environ Model Softw 23(7):893905

Decurtins S (1992) Hydro-geological investigations in the Mt. Kenya sub-catchment of the Ewaso Ng'iro River. African Study Series, A6. Geographica Bernensia. University of Bern, Switzerland

Etchells TM, Malano HM (2005) Identifying uncertainty in water allocation modelling. In: Zerger A, Argent RM (eds) MODSIM 2005. International congress on modelling and simulation. The Modelling and Simulation Society of Australia and New Zealand Inc, Canberra, Australia, pp 2484-2490

FAO (2003) Preparing for the next generation of watershed management programmes and projects for Africa. In: Brent Swallow NO, Achouri M, Tennyson L (eds) Proceedings of the Africa Regional Workshop. FAO, Nairobi, Kenya

Gichuki FN, Liniger HP, MacMillan LC, Schwilch G, Gikonyo JK (1998) Scarce waters: exploring resource availability, use and improved management. East South Afr Geogr J 8:15-27

Gleick PH (1996) Basic water requirements for human activities: meeting basic needs. Water Int 21(2):83-92

Jaetzold R, Schidt H (1983) Farm management handbook of. Kenya, IIB. Central Kenya Ministry of Agriculture, Nairobi

Japan International Cooperation Agency (JICA) (1992) The national water master plan

Kiteme BP, Gikonyo J (2002) Preventing and resolving water use conflicts in the Mount Kenya highland-lowland system through water users associations. Mt Res Dev 22(4):332-337

Liniger H, Gikonyo J, Kiteme BP, Wiesmann U (2005) Assessing and managing scarce tropical mountain water resources - the case of Mount Kenya and the semiarid upper Ewaso Ng'iro Basin. Mt Res Dev 25(2):163-173

Liu D, Chen Z, Lou Z (2009) A model for the optimal allocation of water resources in a saltwater intrusion area: a case study in Pearl River Delta in China. Water Resour Manag 24:63-89

Mutiga JK, Su Z, Woldai T (2010) Using satellite remote sensing to assess evapotranspiration: case study of the Upper Ewaso Ng'iro North Basin, Kenya. International Journal of Applied Earth Observation and Geoinformation 12(Suppl 1):S100-S108

Ngigi SN (2006) Hydrological impacts of land use changes: water resources management and socioeconomic development of the Upper Ewaso Ng'iro River basin in Kenya. PhD thesis, Delft University of Technology, Delft, The Netherlands

Ngigi SN, Rockström J, Savenije HHG (2006) Assessment of rainwater retention in agricultural land and crop yield increase due to conservation tillage in Ewaso Ng'iro river basin, Kenya. Phys Chem Earth Parts A/B/C, 31(15-16):910-918

Notter B, MacMillan L, Viviroli D, Weingartner R, Liniger HP (2007) Impacts of environmental change on water resources in the Mount Kenya region. J Hydrol 343(3-4):266-278

Odermatt S (2004) Evaluation of mountain case studies by means of sustainability variables: a DPSIR model as an evaluation tool in the context of the north-south discussion. Mt Res Dev 24(4):336341

Perry C, Steduto P, Allen RG, Burt CM (2009) Increasing productivity in irrigated agriculture: agronomic constraints and hydrological realities. Agric Water Manag 96:1517-1524

Purkey DR, Hubber-Lee A, Yates DN, Henamann M, Herrod-Julius S (2007) Integrating a climate change assessment tool into stakeholder-driven water management decision-making processes in California. Water Resour Manag 21:315-329

Raskin P, Hansen E, Zhu Z (1992) Simulation of water supply and demand in the Aral Sea. Region 17(2):55-67

Rural-Focus-Ltd (2004) River abstraction survey. Natural Resource Management Trust, Nanyuki 
Sayeed A (2001) Economy versus environment: how a system with remote sensing and GIS can assist in decisions for water resource management-a case study in the lake Naivasha, Central Rift Valley province, Kenya, ITC, Enschede, 88 pp

SEI (2008) WEAP: Water Evaluation and Planning System, tutorial. Stockholm Environment Institute, Boston Center

The Water Act (2002) Equity in water allocation. In: M.o.W. and Irrigation (eds), Republic of Kenya, Nariobi

Ubbels A, Verhallen AJM (2001) Collaborative planning in integrated water resources management: the use of decision support tools. Integrated Water Resources Management, Symposium Proceedings, April 2000, IAHS Publication No. 272

UN (2002) Report of the world summit on sustainable development. United Nations, Johannesburg

UN (2005) The millennium development goals report 2005, New York, USA

UNCED (1992) United Nations conference on environment and development. UN Rio Summit, Earth Summit. UN, Rio de Janeiro

UNWATER (2006) Water a shared responsibility: United Nations world water development report 2

Van Heerden JH, Blignaut J, Horridge M (2008) Integrated water and economic modelling of the impacts of water market instruments on the South African economy. Ecol Econ 66(1):105-116

Wiesmann U, Francis NG, Kiteme BP, Liniger HP (2000) Mitigating conflicts over scarce water resources in the highland-lowland system of Mount Kenya. Mt Res Dev 20(1):10-15

Yates D, Sieber J, Purkey D, Huber-Lee A, Galbraith H (2005a) WEAP21: a demand, priority, and preference driven water planning model: part 2, aiding freshwater ecosystem service evaluation. Water Int 30 (4):487-500

Yates D, Sieber J, Purkey D, Huber-Lee A (2005b) WEAP21: a demand-, priority, and preferencedriven water planning model part 1, model characteristics. Water Int 30(4):487-500 